\title{
PRODUCTION AND CHARACTERIZATION OF CELLULOLYTIC ENZYMES BY ASPERGILLUS NIGER AND RHIZOPUS SP. BY SOLID STATE FERMENTATION OF PRICKLY PEAR ${ }^{1}$
}

\author{
TAMIRES CARVALHO DOS SANTOS ${ }^{2}$, GEORGE ABREU FILHO ${ }^{2}$, AILA RIANY DE BRITO $^{3}$, AURELIANO JOSÉ $^{2}$ \\ VIEIRA PIRES ${ }^{4}$, RENATA CRISTINA FERREIRA BONOMO ${ }^{4}$, MARCELO FRANCO ${ }^{*}$
}

\begin{abstract}
Prickly palm cactus husk was used as a solid-state fermentation support substrate for the production of cellulolytic enzymes using Aspergillus niger and Rhizopus sp. A Box-Behnken design was used to evaluate the effects of water activity, fermentation time and temperature on endoglucanase and total cellulase production. Response Surface Methodology showed that optimum conditions for endoglucanase production were achieved at after $70.35 \mathrm{~h}$ of fermentation at $29.56^{\circ} \mathrm{C}$ and a water activity of 0.875 for Aspergillus niger and after $68.12 \mathrm{~h}$ at $30.41^{\circ} \mathrm{C}$ for Rhizopus sp. Optimum conditions for total cellulase production were achieved after $74.27 \mathrm{~h}$ of fermentation at $31.22^{\circ} \mathrm{C}$ for Aspergillus niger and after $72.48 \mathrm{~h}$ and $27.86^{\circ} \mathrm{C}$ for Rhizopus sp. Water activity had a significant effect on Aspergillus niger endoglucanase production only. In industrial applications, enzymatic characterization is important for optimizing variables such as temperature and $\mathrm{pH}$. In this study we showed that endoglucanase and total cellulase had a high level of thermostability and $\mathrm{pH}$ stability in all the enzymatic extracts. Enzymatic deactivation kinetic experiments indicated that the enzymes remained active after the freezing of the crude extract. Based on the results, bioconversion of cactus is an excellent alternative for the production of thermostable enzymes.
\end{abstract}

Keywords: Filamentous fungi. Response surface methodology. Bioprocesses. Semi-arid region. Enzymatic characterization.

\section{PRODUÇÃO E CARACTERIZAÇÃO DE ENZIMAS CELULOLÍTICAS POR ASPERGILLUS NIGER E RHIZOPUS SP. DURANTE A FERMENTAÇÃO EM ESTADO SÓLIDO DA PALMA FORRAGERIA}

\begin{abstract}
RESUMO - Palma forrageira foi usada como fonte de nutrientes para a produção de enzimas celulolíticas durante a fermentação em estado sólido com auxílio dos fungos filamentosos Aspergillus niger e Rhizopus sp. Os efeitos da ativiade de água, do tempo de fermentação e da temperatura sobre a produção enzimática foram determinados segundo o protocolo padrão de Delineamento Box-Behnken. A condição ideal para produção das enzimas endoglucanase pelo fungo Aspergillus niger foi 70,35 h de fermentação, atividade de água de 0,875 e temperatura de $29,56^{\circ} \mathrm{C}$ enquanto que para o fungo Rhizopus sp. foi $68,12 \mathrm{~h}$ e $30,41^{\circ} \mathrm{C}$. Entretanto, a celulase total produzida pelo fungo Rhizopus sp. foi otimizada em $74,27 \mathrm{~h}$ de fermentação e temperatura de $31,22^{\circ} \mathrm{C} \mathrm{e}$ para o fungo Aspergillus niger foi $72,48 \mathrm{~h}$ e $27,86^{\circ} \mathrm{C}$. A atividade de água só tinha uma influência significativa sobre a endoglucanase para Aspergillus niger. A alta estabilidade dos extratos enzimáticos em diferentes tepenraturas e pH's foram confirmadas após caracterização enzimática, indicando viabilidade em aplicações industriais. Os ensaios de desativação cinética indicaram que essas enzimas permaneceram ativas após o congelamento do extrato bruto. Com base nos resultados, utilizar a palma forrageira com matéria prima em bioprocessos é uma alternativa excelente para a produção de enzimas termoestaveis.
\end{abstract}

Palavras-chave: Fungos Filamentosos. Metodologia de Superfície de Resposta. Bioprocessos. Região semiárida. Caracterização Enzimática.

\footnotetext{
*Corresponding author

${ }^{1}$ Received for publication in $07 / 11 / 2014$; accepted in 10/23/2015.

Master's dissertation work in Environmental Sciences of the first author.

${ }^{2}$ Master in Environmental Sciences, Universidade Estadual do sudoeste da Bahia, Itapetinga, BA, Brazil; tamicarvalhods@gmail.com, georgeabreu16@hotmail.com.

${ }^{3}$ Master in Engineering and Food Science, Universidade Estadual do sudoeste da Bahia, Itapetinga, BA, Brazil; aila.riany16@gmail.com. ${ }^{4}$ Department of Rural Technology and Animal, Universidade Estadual do sudoeste da Bahia, Itapetinga, BA, Brazil; aurelianojvp@yahoo.com.br, bonomorcf@yahoo.com.br.

${ }^{5}$ Department of Exact Sciences and Technology, Universidade Estadual de Santa Cruz, Ilheus, BA, Brazil; marcelofranco@pq.cnpq.br.
} 


\section{INTRODUCTION}

The caatinga is an exclusively Brazilian biome that covers around $850,000 \mathrm{~km}^{2}$ and represents approximately $10 \%$ of the national territory. A large portion of this biome is located in the Brazilian arid and semi-arid regions, which account for $89.3 \%$ of Northeastern Brazil (OLIVEIRA et al., 2010).

Prickly pear cactus is a rustic, of Mexican origin that is adapted to dry conditions (NOBEL et al., 2002; NOBEL; ZUTTA, 2008). The prickly pear fodder is well adapted to the conditions of the Brazilian semi-arid region, enduring long periods of drought due to its physiological properties such as its efficient photosynthetic process (VASCONCELOS et al., 2007). In the Brazilian semi-arid region, the use of prickly pear as animal feed in diverse livestock production systems is due to its high level of total digestive nutrients, carbohydrates, ash, vitamins and iron. In addition, prickly pear can be used in landscaping, conservation and remediation of soils, and in the production of medicines, cosmetics and colorants (FERREIRA et al., 2003; CHIACCHIO et al., 2006).

Prickly pear contains a high amount of total digestible nutrients, and has higher levels of soluble carbohydrates, ash, vitamins, nitrogen and iron content. It also has a relatively high concentration of calcium $(3 \%)$, potassium $(2.5 \%)$ and phosphorus $(0.15 \%)$ and low levels of dry matter $(11 \%)$, crude protein $(4 \%)$, neutral detergent fiber $(26 \%)$ and acid detergent fiber (18\%) (ARAUJO et al., 2005; DUBEUX et al., 2006; SANTOS et al., 2015).

In Brazil, the economic use of prickly pear in animal feed is limited to non-industrial production processes. However, because of its composition, this plant can be used as a raw material for the production of highly useful products such as bioethanol, enzymes and flavor compounds. Enzymes are proteins that act as catalysts to accelerate the speed of chemical reactions and are frequently commercially produced for use in a variety of industrial applications. Commercial enzymes are currently used in food, pharmaceutical, effluent-treatment, textile, paper and cellulase industries (SOCCOL et al., 2010).

The use of enzyme extracts in the industrial processes can increase economic efficiency both in the production process and in the commercialized products. However, this is limited by the high production cost of enzymes. Currently, synthetic culture media is used for enzyme production, which elevates the production costs. These costs may be reduced through the use of plant biomass as a source of microorganism culture. As such, the use of biomass as the raw material for the production of compounds with industrial applications through biological, thermal and/or chemical processes are becoming more popular with the advancements in technology (GALEMBECK et al., 2009; GHORAI et al., 2009; BELMESSIKH et al., 2013).

Therefore, optimizing the production of enzyme extracts using renewable natural resources such as culture media for the growth of microorganisms may reduce production costs (PELIZER et al., 2007; AMIN et al., 2013). In this sense, it is necessary to study the application of prickly pear as a culture medium for the growth of microorganisms and optimize enzyme extract production (SANTANA et al., 2012).

The objective of this study was to investigate the use of prickly pear cv. Miúda (Nopalea cochenillifera (L.) Salm Dyck) as the main raw material for the production of the enzymes endoglucanase (CMCase) and cellulase by solid-state fermentation using Rhizopus sp. and Aspergillus niger. Box-Behnken Design (BBD) and Response Surface Methodology (RSM) were used to determine the optimal conditions for the production of these enzymes. Thus, the results from this study will help transform a low-commercial-value biomass into a product with many commercial applications.

\section{MATERIAL AND METHODS}

\section{Materials}

Base cuts of prickly pear (Nopalea cochenillifera (L.) Salm Dyck), were collected from the Field for Agricultural Studies from the State University of Southwest Bahia (UESB) located in Itapetinga, Bahia, Brazil, in January 2012. The base cuts consisted of the oldest pads, which contain a higher percentage of fibers relative to newer pads. After the pads were washed in running water, they were dried in an oven at $65^{\circ} \mathrm{C}$ for 24 hours and ground in a Wiley mill to an approximate granulometry of $2 \mathrm{~mm}$. The final water content of the sample after drying was $2 \%(\mathrm{~m} / \mathrm{m})$, determined with an infrared moisture analyzer (SHI-MOC-63U; Shimadzu, Kyoto, Japan). The chemical characterization of the prickly pear sample is shown in Table 1. Values are presented as mean \pm SD from 6 replicates.

\section{Microorganisms and culture conditions}

The fungi Aspergillus niger and Rhizopus sp. were provided by the Laboratory of Agro-Industrial Waste Use (LABRA-UESB), where all the experiments were conducted. Microorganisms were inoculated in potato dextrose agar medium (Himedia, Mumbai, India) and incubated for 7 days at $35^{\circ} \mathrm{C}$ in a temperature-controlled incubator (SL 222; Solab, Piracicaba, Brazil). The spores were collected using $0.01 \%(w / v)$ Tween 80 (Vetec, Duque de Caxias, Brazil) and counted with a Neubauer chamber and a binocular microscope (L1000; Bioval, São Paulo, Brazil). 
Table 1. Chemical characterization ( $\mathrm{g} \mathrm{kg}^{-1}$ of dry weight) of the cactus pear (Nopalea cochenillifera). Values are presented as mean \pm SD from 6 replicates.

\begin{tabular}{|c|c|}
\hline Nutrient & $\begin{array}{c}\text { Composition } \\
\text { ( } \mathrm{g} \mathrm{kg}^{-1} \text { of dry weight) }\end{array}$ \\
\hline neutral detergent soluble fiber ${ }^{a}$ & $654.90 \pm 0.55$ \\
\hline acid detergent soluble fiber $^{a}$ & $386.00 \pm 0.55$ \\
\hline non-fibrous carbohydrate ${ }^{b}$ & $157.16 \pm 0.55$ \\
\hline total carbohydrate ${ }^{b}$ & $811.36 \pm 0.55$ \\
\hline lignin $^{\mathrm{c}}$ & $66.74 \pm 0.55$ \\
\hline cellulose $^{\mathrm{c}}$ & $319.26 \pm 0.55$ \\
\hline hemicellulose ${ }^{\mathrm{c}}$ & $268.90 \pm 0.55$ \\
\hline mineral material $^{\mathrm{c}}$ & $103.02 \pm 0.55$ \\
\hline neutral-insoluble ashes ${ }^{d}$ & $73.32 \pm 0.85$ \\
\hline acid-insoluble ashes $^{\mathrm{d}}$ & $66.14 \pm 0.75$ \\
\hline ether extract ${ }^{c}$ & $32.98 \pm 1.05$ \\
\hline total protein ${ }^{\mathrm{c}}$ & $52.64 \pm 1.25$ \\
\hline non-proteic nitrogen ${ }^{\mathrm{d}}$ & $7.25 \pm 0.75$ \\
\hline neutral detergent non-soluble nitrogen ${ }^{\mathrm{d}}$ & $2.22 \pm 0.55$ \\
\hline acid detergent non-soluble nitrogen ${ }^{\mathrm{d}}$ & $1.56 \pm 0.55$ \\
\hline
\end{tabular}

Methodologies: ${ }^{\text {a }}$ Van Soest et al. (1991); ${ }^{\text {b }}$ Sniffen et al. (1992);

${ }^{\mathrm{c}}$ AOAC (1995); ${ }^{\mathrm{d}}$ Silva \& Queiroz (2002).

\section{Solid state fermentation}

Fermentation reactions were performed in an Erlenmeyer flask containing $10 \mathrm{~g}$ of residue. A spore suspension consisting of $10^{8}$ spores per gram substrate was prepared. Afterwards, sterile water was added to the medium to adjust the moisture content. The cultures were performed according to the experimental design described below.

\section{Experimental design}

A Box-Benhnken Design with 18 runs including 4 repetitions in the central point was implemented to evaluate the influence of fermentation temperature, water content and fermentation time on the production of enzyme extracts. Coded and real values of variables are shown in Table 2 .

Table 2. Coded levels and real values for each factor under study in solid state fermentation.

\begin{tabular}{lllllll}
\hline Factorial design in coded values & & \multicolumn{3}{l}{ Factorial design in real values } \\
\hline Run & $\left(\mathrm{X}_{1}, \mathrm{~h}\right)$ & $\left(\mathrm{X}_{2}, \mathrm{a}_{\mathrm{w}}\right)$ & $\left(\mathrm{X}_{3},{ }^{\circ} \mathrm{C}\right)$ & $\left(\mathrm{X}_{1}, \mathrm{~h}\right)$ & $\left(\mathrm{X}_{2}, \mathrm{a}_{\mathrm{w}}\right)$ & $\left(\mathrm{X}_{3},{ }^{\circ} \mathrm{C}\right)$ \\
1 & -1 & -1 & -1 & 24 & 0.786 & 25 \\
2 & -1 & -1 & +1 & 24 & 0.786 & 35 \\
3 & +1 & -1 & -1 & 120 & 0.786 & 25 \\
4 & +1 & -1 & +1 & 120 & 0.786 & 35 \\
5 & -1 & +1 & -1 & 24 & 0.903 & 25 \\
6 & -1 & +1 & +1 & 24 & 0.903 & 35 \\
7 & +1 & +1 & -1 & 120 & 0.903 & 25 \\
8 & +1 & +1 & +1 & 120 & 0.903 & 35 \\
9 & 0 & -1 & 0 & 72 & 0.786 & 30 \\
10 & 0 & +1 & 0 & 72 & 0.903 & 30 \\
11 & -1 & 0 & 0 & 24 & 0.865 & 30 \\
12 & +1 & 0 & 0 & 120 & 0.865 & 30 \\
13 & 0 & 0 & -1 & 72 & 0.865 & 25 \\
14 & 0 & 0 & +1 & 72 & 0.865 & 35 \\
15 & 0 & 0 & 0 & 72 & 0.865 & 30 \\
16 & 0 & 0 & 0 & 72 & 0.865 & 30 \\
17 & 0 & 0 & 0 & 72 & 0.865 & 30 \\
18 & 0 & & 0 & 0.865 & 30 \\
\hline
\end{tabular}




\section{Enzymatic extraction}

After the fermentation process, enzymes were mechanically extracted using $5 \mathrm{~mL}$ of $50 \mathrm{mM}$ sodium citrate buffer ( $\mathrm{pH} 4.8$ ) for each $1 \mathrm{~g}$ of residue. The resulting enzyme extract was collected and centrifuged at $100 \mathrm{~g}$ (CT-6000R; Cientec, Piracicaba, Brazil) for $10 \mathrm{~min}$ at $4^{\circ} \mathrm{C}$.

\section{Determination of endoglucanase (CMCase) activity}

CMCase activity was based on the amount of reducing sugars produced by the degradation of carboxymethyl cellulose (Cromoline, Paraná, Brazil). 2\% (p/v) carboxymethyl cellulose was diluted in $50 \mathrm{mM}$ sodium citrate solution, $\mathrm{pH} 4.8$. The dinitrosalicylic acid (DNS) (Sigma-Aldrich, Missouri, EUA) method was used for quantification of enzyme activity (MILLER, 1959; GHOSE, 1987). Reaction assays were conducted by incorporating 0.5 $\mathrm{mL}$ of $50 \mathrm{mM}$ sodium citrate buffer ( $\mathrm{pH} 4.8), 0.5 \mathrm{~mL}$ enzyme extract and $0.5 \mathrm{~mL}$ carboxymethyl cellulose ( $2 \%$ per volume) to an assay tube. A negative control reaction did not contain CMC. The blank assay contained $0.5 \mathrm{~mL}$ of DNS and $0.5 \mathrm{~mL}$ sodium citrate buffer. The reactions were incubated in a bacteriological incubator SL 222/CFR (Solab, Piracicaba, Brazil) at $50^{\circ} \mathrm{C}$ for $10 \mathrm{~min}$. The reactions were stopped by the addition of $0.5 \mathrm{~mL}$ DNS. After that, the tubes were submerged in boiling water for 5 min. Samples were diluted with the addition of 6.5 $\mathrm{mL}$ distilled for absorbance measurements at $540 \mathrm{~nm}$ in a BEL PHOTONICS SF200DM spectrophotometer (BEL, Osasco, Brazil). activity

Determination of total cellulase (FPase)

The activity of total cellulase (FPase) (exoglucanase and endoglucanase complex), expressed as filter paper activity, was determined by measuring sugars released during the degradation of a Whatman $\mathrm{n}^{0} .1$ filter paper strip $(1.0 \times 6.0 \mathrm{~cm})$. 1 $\mathrm{mL} 50 \mathrm{mM}$ sodium citrate buffer ( $\mathrm{pH} 4.8), 0.5 \mathrm{~mL}$ enzyme extract and a filter paper strip were added to a tube. Another tube contained $1 \mathrm{~mL}$ of the same buffer solution and $0.5 \mathrm{~mL}$ of enzyme extract. A $3^{\text {rd }}$ tube (negative control) contained $1.5 \mathrm{~mL}$ buffer and a filter paper strip. The blank contained $0.5 \mathrm{~mL}$ buffer and $0.5 \mathrm{~mL}$ of DNS. The samples were incubated at $50^{\circ} \mathrm{C}$ for $1 \mathrm{~h}$ (SL 222; Solab). The reaction interrupted by adding $3 \mathrm{~mL}$ of DNS (SigmaAldrich). The tubes were heated in boiling water for $5 \mathrm{~min}$. Samples were diluted with the addition of 20 $\mathrm{mL}$ distilled for absorbance measurements at $540 \mathrm{~nm}$ in a BEL PHOTONICS SF200DM spectrophotometer.

\section{Calibration curve}

The DNS method was used to establish a standard curve for CMCase and FPase activity using 0.1-2.0 g/L glucose standards. One unit of enzyme activity (U) was defined as the amount of enzyme capable of releasing $1 \mu \mathrm{mol}$ reducing sugar/min at $50^{\circ} \mathrm{C}$. Enzyme activity was expressed as $\mathrm{U} / \mathrm{mL}$. CMCase and FPase activity were measured by spectrophotometry at an absorbance of $540 \mathrm{~nm}$.

\section{Determination of thermostability and pH stability}

Thermal stability was determined by measuring enzymatic activity after incubation of the enzymes in a water bath at $20,40,60,80$ and $100^{\circ} \mathrm{C}$ for 0-240 min. Aliquots were removed after 10, 30, $60,90,180$ and $240 \mathrm{~min}$ and immediately placed on ice for enzymatic activity assays. The results are expressed as residual activity (\%), the enzymatic activity that remained active after the incubation period.

$\mathrm{pH}$ stability was determined by measuring the enzymatic activity after incubation of the enzymes in sodium citrate buffer at $\mathrm{pH} 3,4,5,6,7$ and 8 . Aliquots were removed after 10, 30, 60, 90, 180 and $240 \mathrm{~min}$ and kept on ice until analysis. The results are expressed as residual activity (\%). The activity of each enzyme was measured in triplicate.

\section{Enzymatic deactivation kinetics}

Aliquots of the enzymatic extracts were stored at $4^{\circ} \mathrm{C}$ and $-25^{\circ} \mathrm{C}$ and removed at $24,48,72$, 96, 120 and $144 \mathrm{~h}$ to determine enzymatic activity. The activity of each enzyme was evaluated in triplicate.

\section{Statistical analysis}

All statistical analyses were conducted using the Statistical Analysis System, version 9.3, with RSREG procedure (SAS Institute Inc., Cary, NC, USA). To validate the adjusted model, the optimized values of the independent variables $\mathrm{X}_{1}$ (fermentation time), $\mathrm{X}_{2}$ (water activity) and $\mathrm{X}_{3}$ (fermentation temperature) were used in the same initial experimental procedure in order to verify the prediction power of the developed models by comparing the theoretical predicted data with the experimental data.

\section{RESULTS AND DISCUSSION}

Analysis of variance (ANOVA) was used to evaluate which factors had a significant effect on the enzymatic activity of CMCase and FPase from Aspergillus niger and Rhizopus sp. (Table 3) and parameter estimation analyses were conducted for Central Composite Rotatable Design. 
ANOVA for the models was performed and model significance was examined using Fisher's statistical test (F-test) applied to significant differences between sources of variation in experimental results, i.e., the significance of the regression (SOR), the lack of fit (LOF), and the coefficient of multiple determination $\left(\mathrm{R}^{2}\right)$. Since the full second order models (models containing both parameter interactions) not accepted by the mentioned tests, they improved by the elimination of the model terms until the determined conditions were met. All factors that were not significant at $10 \%$ were then pooled into the error term and a new reduced model was obtained for response variables by regression analysis using only the previously listed significant factor.

Table 3. ANOVA for response surface quadratic models for cellulolytic enzymes productions using the Aspergillus niger and Rhizopus sp. in solid state fermentation of prickly palm cactus.

\begin{tabular}{|c|c|c|c|c|c|}
\hline & DF & $\mathrm{SS}$ & MS & F-value & $p$-value \\
\hline \multicolumn{6}{|c|}{ Aspergillus niger } \\
\hline \multicolumn{6}{|c|}{ Endoglucanase } \\
\hline Model & 4 & 16.83383 & 4.20846 & 11.52 & 0.0003 \\
\hline Error & 13 & 4.74997 & 0.36538 & & \\
\hline Lack of fit & 14 & 21.45092 & 1.53221 & 34.59 & \\
\hline Pure error & 3 & 0.13288 & 0.04423 & & \\
\hline Total & 17 & 21.58380 & & & \\
\hline $\mathrm{R}^{2}$ & 0.78 & & & & \\
\hline \multicolumn{6}{|c|}{ Total celulase } \\
\hline Model & 6 & 1569.50352 & 261.58392 & 20.20 & $<0.0001$ \\
\hline Error & 11 & 142.47331 & 12.95210 & & \\
\hline Lack of fit & 14 & 1711.90944 & 122.27925 & 5443.34 & \\
\hline Pure error & 3 & 0.06739 & 0.02246 & & \\
\hline Total & 17 & 1711.97683 & & & \\
\hline $\mathrm{R}^{2}$ & 0.92 & & & & \\
\hline \multicolumn{6}{|c|}{ Rhizopus sp. } \\
\hline \multicolumn{6}{|c|}{ Endoglucanase } \\
\hline Model & 4 & 55.45346 & 13.86336 & 10.19 & 0.0006 \\
\hline Error & 13 & 17.68501 & 1.36039 & & \\
\hline Lack of fit & 14 & 73.05206 & 5.21801 & 181.18 & \\
\hline Pure error & 3 & 0.08640 & 0.02880 & & \\
\hline Total & 17 & 73.13846 & & & \\
\hline $\mathrm{R}^{2}$ & 0.76 & & & & \\
\hline \multicolumn{6}{|c|}{ Total celulase } \\
\hline Model & 4 & 207.97351 & 51.99338 & 23.62 & $<0.0001$ \\
\hline Error & 13 & 21.02796 & 1.61754 & & \\
\hline Lack of fit & 14 & 228.97498 & 16.35536 & 1851.83 & \\
\hline Pure error & 3 & 0.02650 & 0.00883 & & \\
\hline Total & 17 & 229.00147 & & & \\
\hline $\mathrm{R}^{2}$ & 0.91 & & & & \\
\hline
\end{tabular}

ANOVA outcomes are shown in a Pareto chart (Figure. 1). The absolute value of the magnitude of the standardized estimated effect (the estimate effect divided by the standard error) of each factor is plotted in decreasing order and compared with the minimum magnitude of a statistically significant factor with $99 \%$ confidence $(p=0.01)$, represented by the vertical dashed line.

As shown in figure 1, temperature and fermentation time had a significant effect on the enzymatic activity of endoglucanase and total cellulase in Rhizopus sp. and Aspergillus niger. On the other hand, in Aspergillus niger, the Pareto chart showed that water activity had a significant effect on total cellulase activity. The interactions between temperature, time, and water activity were not significant in the presented models. A second-order polynomial model can describe the behaviors of the studied systems, where the interaction term between the independent variables was not significant $(\mathrm{p}>0.01)$.
Temperature affects the microbial metabolism, regulates growth, spore formation, germination and product formation. At lower temperatures, molecules move slower, enzymes cannot mediate chemical reactions. As the temperature increases, molecules move faster, enzymes speed up metabolism and cells rapidly increase in size. However, after a certain value, all of these activities occur at overly high rates, and enzymes start to denature.

High moisture leads to decreased substrate porosity, which prevents oxygen penetration. On the other hand, low moisture may lead to poor accessibility of nutrients, resulting in poor microbial growth (PANDEY, 2003). Although the water activity of the medium could be attributed to the mass transfer of water and solutes across the microbial cells, its effect on enzyme production was lower compared with temperature and fermentation duration (Figure 1). 

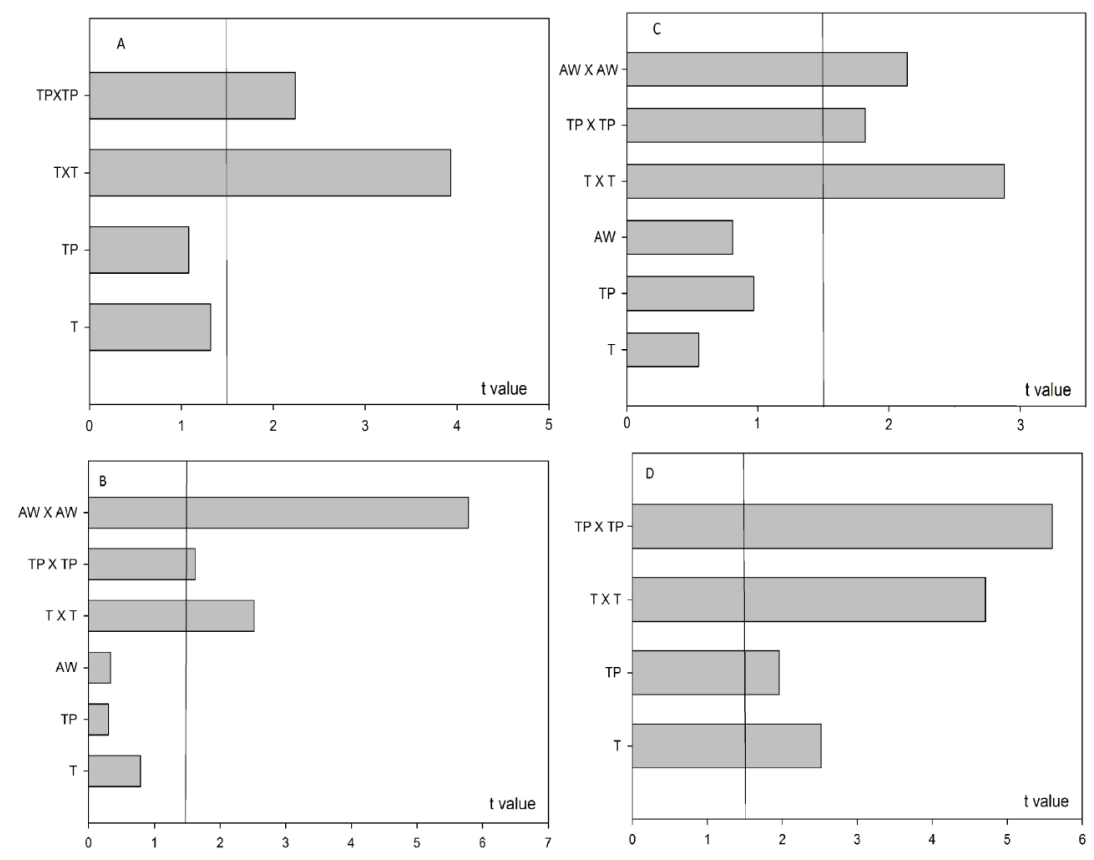

Figure 1. Pareto chart showing the significance of fermentation time $(\mathrm{T})$, fermentation temperature (TP), and water activity (Aw) during solid-state fermentation of cactus. The endoglucanase (A) and total cellulases (B) of Aspergillus niger. The endoglucanase (C) and total cellulases (D) of Rhizopus sp.

Nutrient levels and culture conditions required for microbial growth and enzyme production are affected by fermentation. The production of enzymes is slow at the start of fermentation and then accelerates until it reaches a maximum. From there the high concentration of products inhibits enzyme activity through negative feedback (GOMES et al., 2000; CAMASSOLA et al., 2004; OMEMU et al., 2005).

The reduced models can be described by equations 2-5, in terms of uncoded values.

$\mathrm{E}_{1}=-4,436+0,101 \mathrm{X}_{1}-0,0007 \mathrm{X}_{1}{ }^{2}+0,290 \mathrm{X}_{3}$ $+0,291 \mathrm{X}_{3}^{2}$

$\mathrm{E}_{2}=-3082,32+0,326 \mathrm{X}_{1}+7038,565 \mathrm{X}_{2}+8,481 \mathrm{X}_{3}$

$-0,00240 X_{1}^{2}-4163,338 X_{2}^{2}-0,142 X_{3}^{2}$

$\mathrm{E}_{3}=-59,3372+0,140 \mathrm{X}_{1}+0,042 \mathrm{X}_{3}-0,001 \mathrm{X}_{1}^{2}$ $-0,065 \mathrm{X}_{3}^{2}$

$\mathrm{E}_{4}=-71,17559+0,256 \mathrm{X}_{1}+5,051 \mathrm{X}_{3}-0,002 \mathrm{X}_{1}^{2}$ $-0,085 \mathrm{X}_{3}^{2}$

in which $E_{1}$ and $E_{2}$ represent the activity of endoglucanase and total cellulases for Aspergillus niger, respectively; $\mathrm{E}_{3}$ and $\mathrm{E}_{4}$ represent the activity of endoglucanase and total cellulases for Rhizopus $s p$, respectively; and $\mathrm{X}_{1}, \mathrm{X}_{2}$ and $\mathrm{X}_{3}$ correspond to fermentation time, activity and fermentation temperature, respectively.

Using the response surface method (RSM), with the water-activity value fixed in the optimal condition, the relationship between factors and response can be better understood. The derivatives of equations 2-5 show that temperature and fermentation duration affect enzymatic activity (Figure 2).
In Aspergillus niger, the greatest endoglucanase and total cellulase activity were 4.165 $\mathrm{U} / \mathrm{mL}$ and $30.923 \mathrm{U} / \mathrm{mL}$ after 70.35 and $74.27 \mathrm{~h}$, respectively. In Rhizopus $s p$. these values were 68.12 $\mathrm{h}$ and $7.859 \mathrm{U} / \mathrm{mL}$ for endoglucanase and $72.48 \mathrm{~h}$ and $13.571 \mathrm{U} / \mathrm{mL}$ for total cellulases.

To validate the models, three repeated experiments were performed under the optimal conditions to test the suitability of the model. The enzyme activities identified by the tests were 3.921 $\mathrm{U} / \mathrm{mL}$ for endoglucanase and $29.377 \mathrm{U} / \mathrm{mL}$ for total cellulases produced by Aspergillus niger and 7.545 $\mathrm{U} / \mathrm{mL}$ for endoglucanase and $12.721 \mathrm{U} / \mathrm{mL}$ for total cellulases produced by Rhizopus sp. These models are reliable for predicting endoglucanase and total cellulose production from these fungi.

The optimum temperature was between 27 and $32^{\circ} \mathrm{C}$, which may have been related to the metabolic characteristics of the microorganisms. In Aspergillus niger, the optimum temperature for endoglucanase and cellulase production were 29.56 and $31.22{ }^{\circ} \mathrm{C}$, respectively. In Rhizopus $s p$, the optimum temperatures were $30.41^{\circ} \mathrm{C}$ and $27.86^{\circ} \mathrm{C}$ for endoglucanase and total cellulose production, respectively. In filamentous fungi, the temperature directly influences spore germination, growth and formation of products. In practically all the solidstate fermentation processes, temperature was a critical factor in enzyme production due to the metabolic heat generated during the reaction, because in addition to the difficulty to mix the solid medium, most of the substrates utilized have low thermal conductivity (SANTOS et al., 2012). 

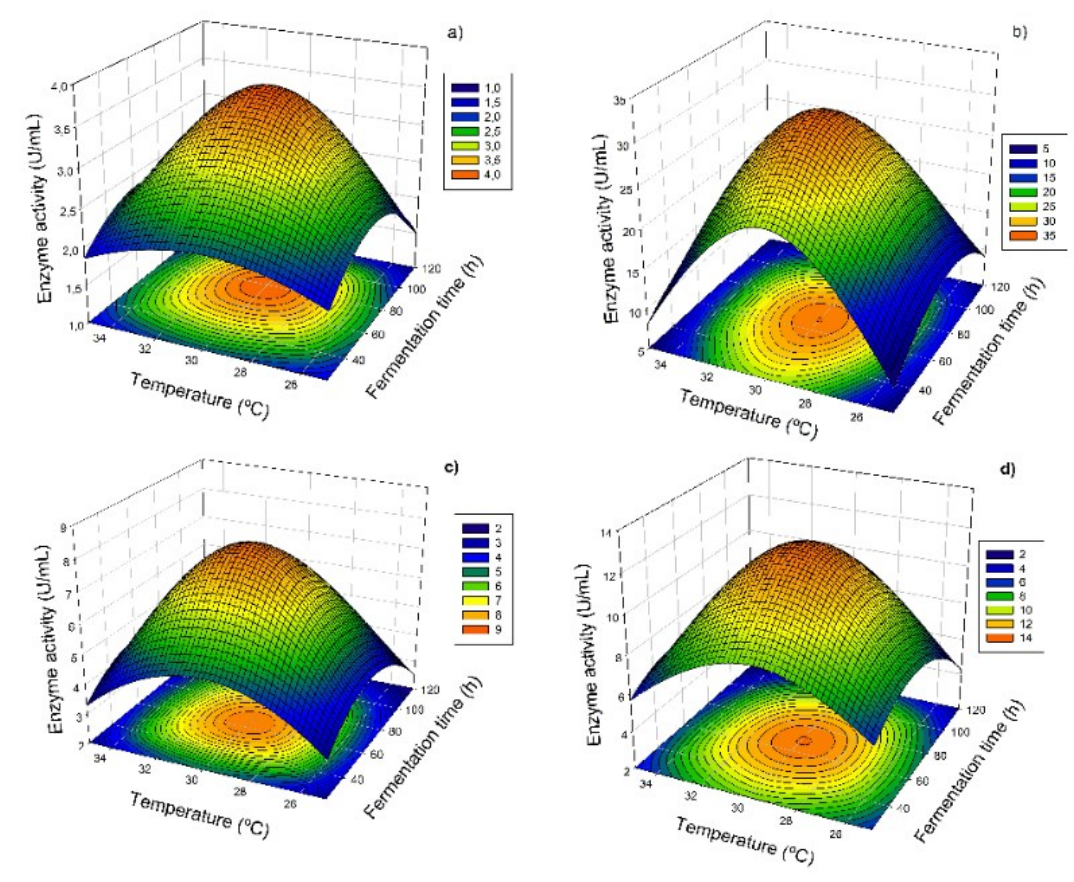

Figure 2. Response surface plots of (A) endoglucanase, (B) total cellulases of Aspergillus niger, (C) Endoglucanase and (D) total cellulases of Rhizopus sp production during solid-state fermentation of cactus.

In solid-state fermentation, water activity is a critical factor for fungi growth and controlling its activity is essential for bioprocess optimization. The appropriate water content for the substrate enables the formation of a water film on the surface, which facilitates the dissolution and transfer of nutrients and oxygen. However, spaces between the particles should remain free to allow the diffusion of oxygen and the dissipation of heat (GERVAIS; MOLIN, 2003; SANCHEZ, 2009;). In this study, the optimal water activity for total cellulase production from Aspergillus niger was 0.875 .

The water activity values in this study were ideal for the growth of fungi; therefore, the evaluated values were suitable for enzyme production. Water activity influences microbial growth and biological and enzymatic processes (GERVAIS; MOLIN, 2003). Each microorganism has a minimum water activity limit for metabolic activities to occur.

The presence of pre-existing nutrients in the prickly pear contributed to the growth of the microorganism, and when nutrient levels decreased due to consumption by the fungi, enzyme production decreased. Enzyme production starts out slow and then accelerates until it reaches a peak. Other microorganisms can also produce enzymes for industrial use. For example, endoglucanases are also produced by actinomycetes such as Streptomyces T31 , which can produce $40.3 \mathrm{U} / \mathrm{mL}$ in $1.5 \% \mathrm{CMC}$, ammonium sulfate, urea and peptone. Furthermore. $0.59 \mathrm{U} / \mathrm{mL}$ total cellulases were produced by Penicilium brasilianum IBT 20888 cultivated in a bioreactor in medium containing yeast extract and wood from a type of pine tree subjected to steam explosion (JANG; CHEN, 2003; JORGENSEN;
OLSSON, 2006; SANTOS et al., 2011;).

In all the aforementioned studies, incubation times from 7 to 10 days, which is much longer than those utilized in the present study. It is worth noting that no inductors or supplements other than fresh prickly pear were used. The substrate was also not pre-hydrolyzed, demonstrating that the enzymes were constitutive.

The utilization of solid-state fermentation using lignocellulosic biomass and inducers has also contributed to increase the cellulolytic enzymes production in order to reduce cost, emphasizing the importance of optimizing the fermentation process and the ability of microorganisms to express enzymes (FOROOTANFAR et al., 2011; OSMA et al., 2011; AHMAD et al., 2013; MANAVALAN et al., 2013).

The design of the bioreactor is also important for maximizing cellulolytic enzyme production via solid-state fermentation. The bioreactor should also provide the optimum environment for microorganism growth and consider parameters such as aeration, humidity, agitation and temperature (COUTO; SANROMÁN, 2005; RABELO et al., 2011).

In general, the use of enzyme extracts in industrial processes reduces the risk of contamination by microorganisms, promotes solubility of substrates and products, increases reaction rates and increases the diffusion coefficient of the substrates; however, under elevated temperature and $\mathrm{pH}$ conditions, enzymatic activity is significantly reduced (PALMA-FERNANDEZ et al., 2002; GOMES et al., 2007).

Enzymatic characterization is important for

Rev. Caatinga, Mossoró, v. 29, n. 1, p. 222 - 233, jan. - mar., 2016 
optimizing variables such as temperature and $\mathrm{pH}$, which are the most relevant for industrial applications.

According to the thermal stability results, endoglucanase (Figure. 3A) produced by Aspergillus niger maintained its activity for 60 minutes at $60^{\circ} \mathrm{C}$, and then the activity decreased to $20 \%$ of its relative activity after 240 minutes. However, in endoglucanase produced by Rhizopus sp. (Figure. 3B), its activity increased until 90 minutes,
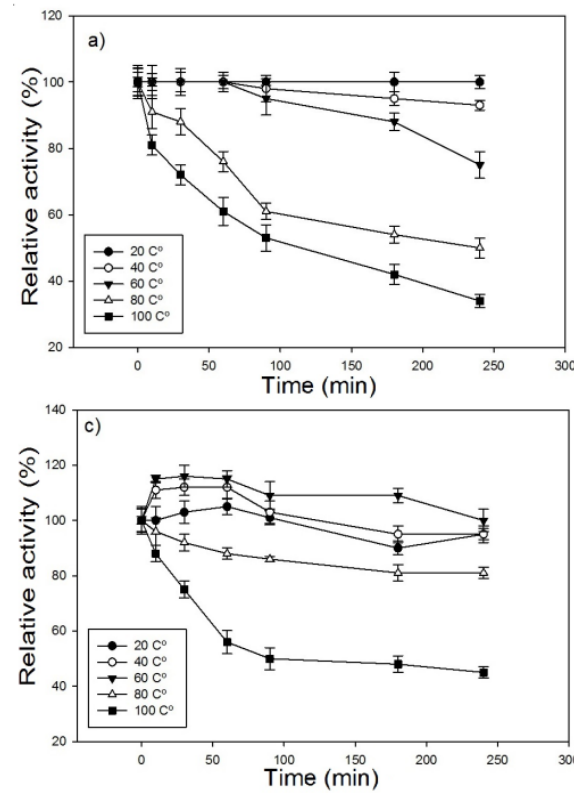

Figure 3. Thermostability of the enzymes (A) Endoglucanase, (B) total cellulases extracted of Aspergillus niger and (C) Endoglucanase, (D) total cellulases extracted Rhizopus sp.

At $60^{\circ} \mathrm{C}$, the residual activity of total cellulase from Aspergillus niger was $100 \%$ at 90 minutes of incubation, with an increase of approximately $20 \%$ during the 40 initial minutes of incubation. However, at $60^{\circ} \mathrm{C}$, the residual activity of total cellulose from Rhizopus sp. remained at $100 \%$ until 250 minutes. After 20 minutes at $100^{\circ} \mathrm{C}$, the residual activity of total cellulase from Rhizopus sp. was approximately $70 \%$, whereas the residual activity was $30 \%$ when produced by Aspergillus.

In Aspergillus niger in purple mombin waste, the maximum activity of endoglucanase and total cellulase occurred at 50 and $60^{\circ} \mathrm{C}$, respectively (SANTOS et al., 2013). The increased enzyme activity was due to temperature-induced activation, in which atoms acquired more energy and thus a greater tendency to move. After this period, there is denaturation or thermal deactivation caused by the rupture of weak interactions holding the globular protein structure together. Under the conditions studied, the optimal working temperature of the cellulase complex was between 50 and $60^{\circ} \mathrm{C}$.

From Figure 3, A-D, we can assume that the thermostability of Rhizopus sp. enzymes were superior to those produced by Aspergillus niger. Endoglucanase and total cellulase produced by the fungi $A s$ -
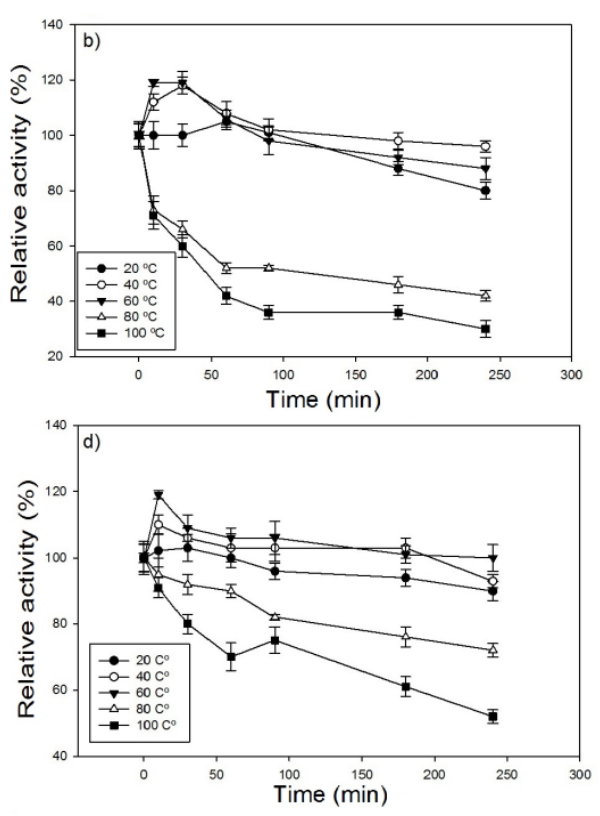

considering the temperature interval of 20 to $60^{\circ} \mathrm{C}$; at $60^{\circ} \mathrm{C}$, the relative enzymatic activity did not reduce until the end of the analysis at 240 minutes. At $80^{\circ} \mathrm{C}$, the relative enzymatic activity reduced by $20 \%$ after 60 minutes for endoglucanase produced by the fungus Aspergillus niger (Figure. 3A), whereas at the same temperature this $20 \%$ reduction was only observed at 240 minutes in the enzyme produced by Rhizopus sp.

pergillus niger and Rhizopus sp. can be utilized in catalytic steps at temperatures of up to $60^{\circ} \mathrm{C}$ for 240 minutes. Rhizopus endoglucanase can be utilized at temperatures of up to $80^{\circ} \mathrm{C}$. Although incubation at $100^{\circ} \mathrm{C}$ caused a marked reduction in activity for all the evaluated enzymes, the residual activity was higher than $30 \%$ after 180 minutes (Figure. $3 \mathrm{~A}-\mathrm{D}$ ).

At a $\mathrm{pH}$ of 5 and 6 , the residual activity of Aspegillus niger endoglucanase (Figure. 4) was approximately $100 \%$ for 240 minutes, with an elevation of approximately $10 \%$ throughout the assay, and residual activity above $80 \%$ was observed at $\mathrm{pH}$ of 4 , 7 and 9. The residual activity of Rhizopus sp. endoglucanase, however, was $100 \%$ at pH 5 after 240 minutes over the course of the assay and at $\mathrm{pH}$ of 4 , 6 and 7, the residual enzymatic activity was greater than $70 \%$.

The residual activity of Aspergillus niger total cellulases (Figure. 4B) was greater than $100 \%$ until 250 minutes of incubation. At $\mathrm{pH}$ of 5 , its activity increased by $30 \%$ at 90 minutes of incubation. At $\mathrm{pH}$ 6 , a decrease of approximately $10 \%$ was observed. The relative activity exceeded $70 \%$ at $\mathrm{pH}$ of 4,7 and 8 . However, the residual activity of total cellulases produced by Rhizopus sp. (Figure. 4D) was $100 \%$ for only 90 minutes at $\mathrm{pH} 5$ and 6 . After this time, a 
decrease of approximately $10 \%$ was observed until 250 minutes of incubation. At $\mathrm{pH} 4,7$ and 8 , the
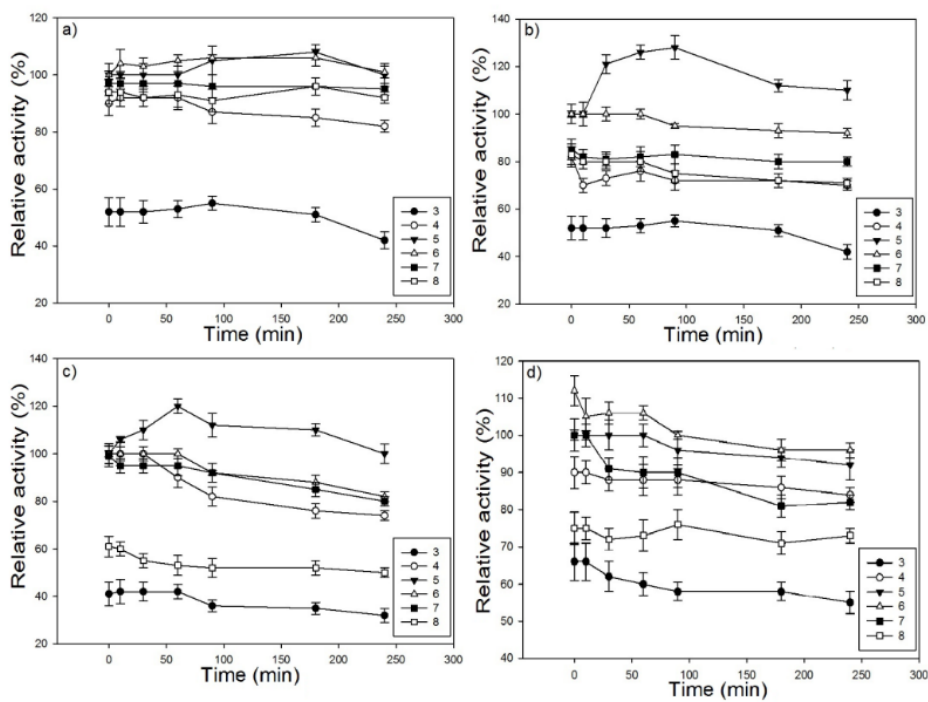

Figure 4. pH stability of the enzymes (A) Endoglucanase, (B) total cellulases from Aspergillus niger and (C) Endoglucanase, (D) total cellulases from Rhizopus sp.

The optimal $\mathrm{pH}$ for endoglucanase and total cellulases activity was 5.0 or 6.0 , similar for other Aspergillus species. The presence of endoglucanase with an optimal $\mathrm{pH}$ of 5.0 and 6.0 in total cellulases was reported for $A$. nidulans (BAGGA et al., 1990). Melanocarpus $s p$. also produced enzymes with higher activity at pH 5.0 and 6.0 (GOMES et al., 2000). Total cellulase from $P$. echinulatum, however, had higher activity at $\mathrm{pH} 4.5$ (CAMASSOLA et al., 2004).

Over time, the reduction in hydrolysis may have been due to enzyme deactivation by temperature and/or the absence of substrate factors in the medium. On the other hand, very short reaction

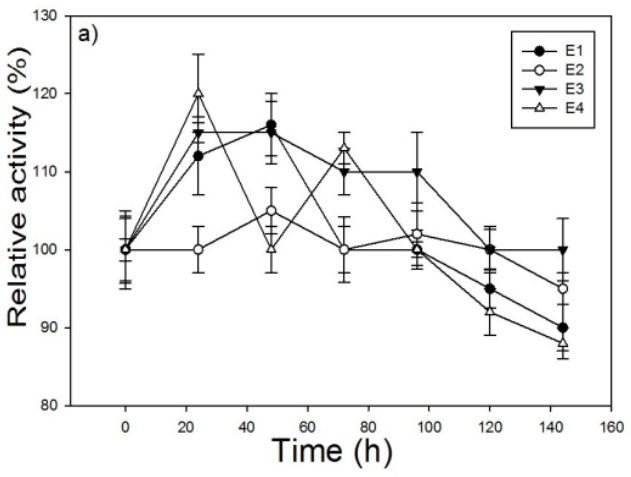

times are not sufficient for the degradation of either the amorphous fraction or the crystalline fraction of cellulose. Thus, the hydrolysis time should be sufficient to ensure that the degradation of total cellulases occurs without enzyme deactivation (ZHANG et al., 2006; RABELO et al., 2011).

Overall, regardless of the fungus, at $\mathrm{pH} 5$ and 6 it was observed that the residual activities of endoglucanase and total cellulases were greater than 95\% during after 240 minutes of incubation, which suggests these enzymes maintained their structural stability, indicating that they are acid-tolerant and, thus, can be used in industrial processes with acid characteristics.

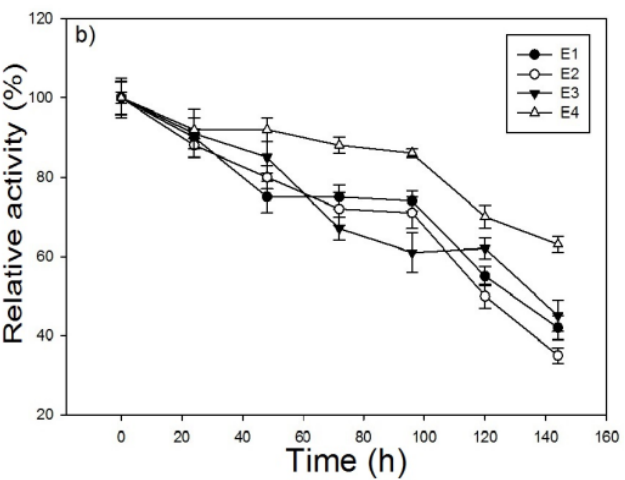

Figure 5. Kinetics of enzyme inactivation after storage at $4^{\circ} \mathrm{C}(\mathrm{A})$ or $-25^{\circ} \mathrm{C}(\mathrm{B}) . \mathrm{E}_{1}$ and $\mathrm{E}_{2}$ represent endoglucanase and total cellulose, respectively from Aspergillus niger. $\mathrm{E}_{2}$ and $\mathrm{E}_{3}$ represent endoglucanase and total cellulases, respectively from Rhizopus $s p$.

To evaluate the activity profile of enzymes after storage, enzymatic deactivation experiments were performed at two different temperatures (Figure. 5). Enzymatic deactivation may be influenced by factors such as temperature, $\mathrm{pH}$, hydrodynamic forces, and absence of substrate, among others (AGUIAR; SERGIO, 2011). At a freezing temperature $\left(-25^{\circ} \mathrm{C}\right)$, there was no sudden loss in endoglucanase or total cellulase activity. Even after 144 hours, the relative activity of the crude enzyme extract was over $85 \%$. 
Freezing led to an approximately $15 \%$ increase in the relative activity at a given moment; this can be explained by the effect of freezing on the original structure of the proteins. Freezing interferes with water activity, causing the polypeptide chain to restructure; therefore after thawing, the enzyme may have acquired a new configuration that affected the enzymatic activity. Freezing also interrupts chemical reactions and biological activities (AGUIAR; SERGIO, 2011). However, at coolant temperature $\left(4^{\circ} \mathrm{C}\right)$, there was degradation due to microbial growth in the enzyme extract (COLLA; PRENTICEHERNANDE, 2003)

\section{CONCLUSION}

In this study, the Box-Benhnken Design was employed to predict the combined effects of cultivation conditions on cellulolytic enzyme production from of filamentous fungi. Based on the results, the use of prickly pear as substrate and Aspergillus niger and Rhizopus sp. was satisfactory for the production of endoglucanase and total cellulase. Experiments carried out in optimal conditions validated the statistical models. The enzymes were highly tolerant to a wide range of temperature and $\mathrm{pH}$, which indicates great relevance for industrial applications. The cellulase complex is not significantly deactivated if frozen at $-25^{\circ} \mathrm{C}$ for up to 144 hours, but loses approximately $60 \%$ of its activity if stored at $4^{\circ} \mathrm{C}$. Since prickly pear is a lowcost organic substrate with high incidence in the Brazilian Northeast semi-arid region, it is a potential nutrient source for the production of enzymes of industrial interest.

\section{ACKNOWLEDGEMENTS}

We are thankful to Bank of Northeast of Brazil (BNB), Coordination of Higher Education and Graduate Training (CAPES), National Council for Scientific and Technological Development (CNPq), and to Bahia Research Foundation (FAPESB) for financial support.

\section{REFERENCES}

AGUIAR, C. M.; SERGIO, L. L. Produção de celulases por Aspergillus niger e cinética da desativação celulásica. Acta Scientiarum Technology, Maringá, v. 33, n. 4, p. 385-391, 2011.

AHMAD, Z.; BUTT, M. S.; RIAZ, M. Partial Purification and Charactrization of Xylanase produced from Aspergillus niger using Wheat Bran. Pakistan Journal of Agriculture Science,
Faisalabad, v. 50, n. 3, p. 433-437, 2013.

AMIN, F. et al. Utilization of Wheat Bran for Enhanced Production of Exopoligalacturonase by Penicillium notatum using Response Surface Methodology. Pakistan Journal of Agricultural Sciences, Faisalabad, v. 50, n. 3, p. 469-477, 2013.

AOAC - Association of Official Analytical Chemistry, 1995. Official methods of analysis. $16^{\text {th }}$ ed. AOAC International, Arlington.

ARAÚJO, L. F. et al. Protein Enrichment of Cactus Pear (Opuntia ficus - indica Mill) using Saccharomyces cerevisiae in Solid-State Fermentation. Brazilian Archives of Biology and Technology, Curitiba, v. 48, special, p. 161-168, 2005.

BAGGA, P. S.; SANDHU, D. K.; SHARMA, S. Purification and characterization of cellulolytic enzymes produced by Aspergillus nidulans. Journal of Applied Bacterioloogy, Malden, v. 68, n. 1, p. 61 $-68,1990$.

BELMESSIKH, A. et al. Statistical optimization of cullture médium for neutral protease production by Aspergillus oryzae. Comparative study between solid and submerged fermentations on tomato pomace. Journal of the Taiwan Institute of Chemical Engineers, Taiwan, v. 44, n. 3, p. 377-385, 2013.

CAMASSOLA, M. et al. Characterization of the cellulase complex of Penicillium echinulatum. Biocatalysis and Biotransformation, Madrid, v. 22, n. 5-6, p. 391-396, 2004.

CHIACCHIO, F. P. B.; MESQUITA, A. S.; SANTOS, J. R. Palma forrageira: uma oportunidade econômica ainda desperdiçada para o semiárido baiano. Revista Bahia Agrícola, Salvador, v. 7, n. 3, p. $39-49,2006$.

COLLA， L. M.; PRENTICE-HERNANDE, C. Congelamento e descongelamento - sua influência sobre os alimentos. Vetor - Revista de Ciências Exatas e Engenharias, Rio Grande, v. 13, n. 1, p. 53 $-66,2003$.

COUTO, S. R.; SANROMÁN, M. A. Application of solid-state fermentation to ligninolytic enzyme production. Biochemical Engineering Journal, Illinois, v. 22, n. 3, p. 211-219, 2005.

DUBEUX, J. C. B. et al. Productivity of Opuntia fícus-indica (L.) Miller under different $\mathrm{N}$ and $\mathrm{P}$ fertilization and plant population in north-east Brazil. Journal of Arid Environments, Chubut, v. 67, n. 3, p. 357-372, 2006. 
FERREIRA, C. A. et al. Use of multivariate techniques in genetic divergence evaluation among cactus forage (Opuntia ficus-indica Mill.). Revista Brasileira de Zootecnia, Viçosa, v. 32, n. 6, p. 1560 $-1568,2003$.

FOROOTANFAR, $H$. et al. Purification and biochemical characterization of extracellular laccase from the ascomycete Paraconiothyrium variabile. Bioresource Technology, Trivandrum, v. 102, n. 2, p. 1808-1814, 2011.

GALEMBECK, F.; BARBOSA, C. A. S.; SOUSA, R. A. Aproveitamento Sustentável de Biomassa e de Recursos Naturais na Inovação Química. Química Nova, São Paulo, v. 32, n. 3, p. 571-581, 2009.

GERVAIS, P.; MOLIN, P. The role of water in solid -state fermentation. Biochemical Engineering Journal, Illinois, v. 13, n. 2-3, p. 85-101, 2003.

GHORAI, S. et al. Fungal Biotechnology in Food and Feed Processing. Food Research International, Toronto, v. 42, n. 5-6, p. 577-587, 2009.

GHOSE, T. K. Measurement of cellulase activities. Pure \& Applied Chemistry, Durhan, v. 59, n. 2, p. 257-268, 1987.

GOMES, E. et al. Enzimas termoestáveis: fontes, produção e aplicação industrial. Química Nova, São Paulo, v. 30, n. 1, p. 136-145, 2007.

GOMES, I. et al. Simultaneous production of high activities of thermostable endoglucanase and $\beta$ glucosidase by the wild thermophilic fungus Thermoascus aurantiacus. Applied Microbiology and Biotechnology, New York, v. 53, n. 4, p. 461468, 2000.

JANG, H. D.; CHEN, K. S. Production and characterization of thermostable cellulases from Streptomyces transformant T3-1. World Journal of Microbiology and Biotechnology, Valencia, v. 19, n. 2 , p. 263-268, 2003.

JORGENSEN, H.; OLSSON, L. Production of cellulases by Penicillium brasilianum IBT 20888 Effect of substrate on hydrolytic performance. Enzyme and Microbial Technology, Georgia, v. 38, n. 3/4, p. 381-390, 2006.

MANAVALAN, $T$. et al. Characterization of optimized production, purification and application of laccase from Ganoderma lucidum. Biochemical Enginnering Journal, Illinois, v. 70, n. 1, p. 106$114,2013$.

MILLER, G. L. Use of dinitrosalicylic acid reagent for determination of reducing sugar. Analytical
Chemistry, Washington, v. 31, n. 2, p. 426-428, 1959.

NOBEL, P. S. et al. Temperature limitations for cultivation of edible cacti in California. Madroño, California, v. 49, n. 4, p. 228-236, 2002.

NOBEL, P. S.; ZUTTA, B. R. Tempeture tolerances for stams and roots of two cultivated cacti, Nopalea cochenilliferra and Opuntia robusta: Acclimation, light, and droyght. Journal of Arid Environments, Chubut, v. 72, n. 5, p. 633-642, 2008.

OLIVEIRA, F.T. et al. Palma forrageira: adaptação e importância para os ecossistemas áridos e semiáridos. Revista Verde de Agroecologia e Desenvolvimento Sustentável, Mossoró, v. 5, n. 4, p. 27-37, 2010.

OMEMU, A.M. et al. Hydrolysis of raw tuber starches by amylase of Aspergillus niger AM07 isolated from the soil. African Journal of Biotechnology, Abraka, v. 4, n. 1, p. 19-25, 2005.

OSMA, J. F.; TOCA-HERRERA, J. L.; RODRIGUEZ-COUTO, S. Cost analysis in laccase production. Journal of Environmental Management, California, v. 92, n. 11, p. 2907-2912, 2011

PALMA-FERNANDEZ, E. R.; GOMES, E.; SILVA, R. Purification and characterization of two $\beta$ -glucosidases from the thermophilic fungus Thermoascus aurantiacus. Folia Microbiologica, Praga, v. 47, n. 6, p. 685-690, 2002.

PANDEY, A. Solid-state fermentation. Biochemical Engineering Journal, Illinois, v. 13, n. 2/3, p. 8184, 2003.

PELIZER, L. H.; PONTIERI, M. H.; MORAES, I O. Utilização de resíduos agroindustriais em processos biotecnológicos como perspectiva de redução do impacto ambiental. Journal Technology Management \& Innovation, Santiago, v. 2, n. 1, p. 118-127, 2007.

RABELO, S. C. et al. Production of bioethanol, methane, and heat from sugarcane bagasse in a biorefinery concept. Bioresource Technology, Trivandrum, v. 102, n. 17, p. 7887-7895, 2011.

SANCHEZ, C. Lignocellulosic residues: biodegradation and bioconversion by fungi. Biotechnology Advances, Rehovot, v. 27, n. 21, p. 85-94, 2009.

SANTANA, R. S. M. et al. Produção de amiloglucosidase utilizando como substrato a palma forrageira. Revista Caatinga, Mossoró, v. 25, n. 1, 
p. $188-193,2012$.

SANTOS, T. C. et al. Effect of solid state fermentation on nutritional content and evaluation of degradability in cactus pear. Revista Caatinga, Mossoró, v. 28, n. 3, p. 248- 254, 2015.

SANTOS, T. C. et al. Application of response surface methodology for producing cellulolytic enzymes by solid-state fermentation from the puple mombin (Spondias purpurea L.) Residue. Food Science and Biotechnology, Seoul, v. 22, n. 1, p. 17, 2013 .

SANTOS, T. C. et al. Optimisation of solid state fermentation of potato peel for the production of cellulolytic enzymes. Food Chemistry, Reading, v. 133, n. 4, p. 1299-1304, 2012.

SANTOS, T. C. et al. Optimization of productions of cellulolytic enzymes by Aspergillus niger using residue of mango a substrate. Ciência Rural, Santa Maria, v. 41, n. 12, p. 2210-2216, 2011.

SILVA, J. D. et al. Análise de alimentos: Métodos químicos e biológicos. 3. ed. Viçosa, MG: Editora UFV, 2002. 235 p.

SINGHANIA, R. R. et al. Recent Advances in Solidstate Fermentation. Biochemical Engineering Journal, Illinois, v. 44, n. 1, p. 13-18, 2009.

SNIFFEN, C. J. et al. A net carbohydrate and protein system for evaluating cattle diets: II. Carbohydrate and protein availability. Journal of Animal Science, Champaign, v. 70, n. 7, p. 3562-3577, 1992.

SOCCOL, C. R. et al. Bioethanol from lignocelluloses: Status and perspectives in Brazil. Bioresource Technology, Trivandrum, v. 101, n. 13, p. 4820-4825, 2010.

VAN SOEST, P. J.; ROBERTSON, J. B.; LEWIS, B. A. Methods for Dietary Fiber, Neutral Detergent Fiber, and Nonstarch Polysaccharides in Relation to Animal Nutrition. Journal of Dairy Science. Champaign, v. 74, n. 10, p. 3583-3597, 1991.

VASCONCELOS, A. G. V. et al. Micropropagation of pricly-pear cv. Miúda (Nopalea cochenillifera Salm Dyck). Revista Brasileira de Ciências Agrárias, Recife, v. 2, n. 1, p. 28-31, 2007.

ZHANG, Y. H. P.; HIMMEL, M. E.; MIELENZ, J. R. Outlook for cellulose improvement: Screening and selection strategies. Biotechnology Advanced, Rehovot, v. 24, n. 5, p. 452-481, 2006. 